\title{
転位反応を基盤とした連続反応の開発研究
}

\author{
杉本 健 士
}

\section{Development of Domino Reactions Based on Skeletal Rearrangement}

\author{
Kenji Sugimoto \\ Graduate School of Pharmaceutical Sciences, Tohoku University, \\ 6-3 Aramaki, Aoba-ku, Sendai 980-8578, Japan
}

(Received June 19, 2011)

\begin{abstract}
Domino reactions, which enable formations of several chemical bonds and multi-step transformation in one-pot process, have received much attention as an efficient synthetic methodology to preserve chemists from time-consuming purification protocols and protection-deprotection procedures. Furthermore, the domino processes containing skeletal rearrangement have been utilized for constructions of complex molecules because of their potential that they could afford entirely different valuable structures from readily available simple substrates. We recently developed novel domino reactions including ring enlargement process, which could afford biologically important cyclopentanones and nitrogen heterocycles. In this review, we will describe 1) a novel type of palladium-catalyzed domino insertion-ring expansion reaction of dienylcyclobutanols, which could enable a stereospecific synthesis of (Z)-2-(3-aryl-1-propenyl) cyclopentanones, 2) ruthenium-catalyzed domino ring expansion-insertion reaction of 1-acetylenylcyclobutanols for a construction of 2-alkylidenecyclopentanones, and 3) DIBALH-mediated reductive ring expansion reaction of oximes and studies on the reaction mechanisms. The rationales for the observed stereoselectivities in each reaction are also discussed.
\end{abstract}

Key words_-domino reaction; rearrangement; palladium; ruthenium; DIBALH

\section{1.はじめに}

有機合成の発展により様々な新反応が開発され， 複雑な標的分子への多様なアプローチが開拓されて きている。 これまでに多段階を踏んで達成されてい た標的分子の合成も，近年において新たに開発され た手法により斬新かつ効率的に成し遂げられること も少なくない. 特に, 一度の操作で多段階の変換反 応を実行し, 複数の化学結合を形成させ得る連続反 応は, 煩雑な精製操作の省略や, 保護 - 脱保護の過 程の省略などといつた資材，時間の節約といつた効 率性の向上のみならず，単離の難しい不安定な中間 体をも取り扱うことが可能となることもあり，注目 を集めている。さらに，転位過程を含む連続反応 は，入手容易な単純な基質においても大きな構造変

東北大学大学院薬学研究科（T980-8578 仙台市青葉区 荒巻字青葉 6-3)

現所属: 富山大学大学院医学薬学研究部 (薬学) 薬品 製造学研究室（干930-0194 富山市杉谷 2630)

e-mail: ksugimo@pha.u-toyama.ac.jp

本総説は，平成 22 年度日本薬学会東北支部奨励賞（基 礎薬学部門）の受賞を記念して記述したものである。
化をもたらすため，高度な立体化学の制御下で行う ことで複雑な構造を持つ化合物の構築に用いられて きた. ${ }^{1-6)}$

これまでに福本ら，井原らは，シクロブタノール 類を合成素子として活用し，その環拡大反応を報告 しており，シクロブタノールに隣接する炭素をパラ ジウムによって求電子的に活性化することで転位が 進行し，立体選択的にシクロペンタノン誘導体を与 えることを見い出し，生理活性物質合成にも適用可 能であることを実証している. ${ }^{7-17)}$ 筆者は，この環 拡大反応に注目し, 様々な不飽和結合を持つシクロ ブタノール誘導体の遷移金属による活性化を経る, 転位反応と炭素-炭素結合形成反応との連続反応を 活用した多様な置換様式を持つシクロペンタノン誘 導体の構築を見い出した。

また，医薬品の母核として重要な含窒素複素環の 構築法として， DIBALH を用いたオキシムの還元 的転位反応の一般性の拡張と, 反応機構の解明にも 取り組み, 重要な知見を得ることに成功した.

本稿では，筆者がこれまでに取り組んできた，こ 
れらの転位反応を組み込んだ連続的変換反応につい て，それぞれにおいて観察された立体選択性発現の 機構も含めて概説する。

2. パラジウム触媒を用いたジェニルシクロブタ ノールの連続的環拡大反応 ${ }^{18)}$

ジエン化合物は 0 価のパラジウム触媒存在下ア リールハライドとの位置選択的な挿入反応により $\pi$-アリルパラジウム錯体を形成し，求電子剂として 作用するため，連続的な反応に適用可能であ る. ${ }^{19-22)}$ 筆者は，この知見に着目し， $\pi$-アリルパラ ジウム錯体の生成によるシクロブタノールに隣接す る炭素の求電子的な活性化を行い，これを引き金と した転位反応を伴う連続的挿入一環拡大反応を計画 した (Fig. 1).

はじめに，パラジウム触媒や温度等，種々の条件 を精査したところ，（Z）-ジエンを側鎖とする基質 (Z) -4 とヨードベンゼン (5a) に対して, P $(o \text {-tolyl })_{3}$ と $\mathrm{Ag}_{2} \mathrm{CO}_{3}$ 存在下 $\mathrm{Pd}_{2}(\mathrm{dba})_{3} \cdot \mathrm{CHCl}_{3}$ を作用させる と最も良好な収率 $83 \%$ で成績体を与え，NOE 相関 の確認により， $(Z)$-オレフィンを持つシクロペン タノン $\mathbf{6 a}$ が得られていることが明らかとなった。

一方， $(E)$-ジエンを側鎖とする基質 $(E)-4$ では同 条件下でも目的とした反応は進行しなかった（Fig， 2).

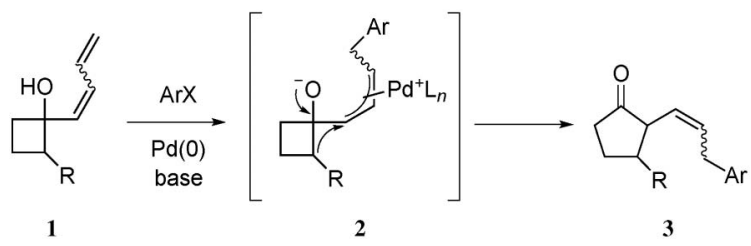

Fig. 1. Pd-catalyzed Insertion-Ring Expansion Reaction

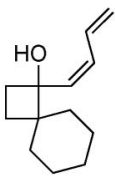

(Z)-4

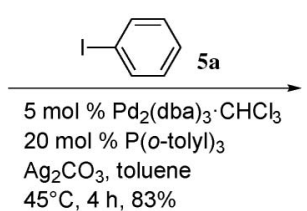
$\mathrm{Ag}_{2} \mathrm{CO}_{3}$, toluen
$45^{\circ} \mathrm{C}, 4 \mathrm{~h}, 83 \%$

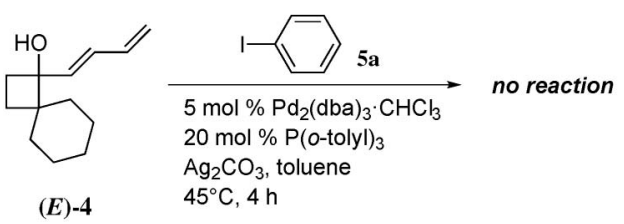

(E)-4

Fig. 2. Reactivity of $(Z)-4$ and $(E)-4$

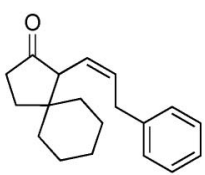

6a
本反応は汎用性が高く, 種々のヨウ化アリールに 対して適用可能であった（Fig. 3)。電子求引性, 電子供与性いずれの置換基を持つヨウ化アリールか らも目的の成績体 $\mathbf{6 b - 6 i}$ を与えることが明らかとな つた。なお，2-bromoiodobenzene (5e) を用いた際 には，本条件下では 2 種のハロゲン原子が区別さ れ，長時間の反応にさらしても，さらにヨウ素部位 で反応した生成物は観察されず，ヨウ素部位のみで 反応が進行した 2-ブロモフェニル成績体を選択的 に与えた。

次に様々な基質について連続反応を試みた（Table 1). シクロブタン環の $\alpha$ 位に直鎖アルキル基を 持つ基質 $(\boldsymbol{Z})$-7 でも目的とした反応が進行し，良 好な収率で相当する成績体 8 を与えた。また，互い にジアステレオマーの関係にある trans- $(Z)$-9 と cis- $(Z)$-9 をそれぞれ本反応に適用したところ， trans- $(Z)-9$ からは trans-10を, cis- $(Z)-9$ からは cis-10 をそれぞれ単一の生成物として与えた。この ことから本反応が立体特異的に進行していることが 明らかとなった。ささらにジエン上 3 位にメチル基を 導入した基質 $(\boldsymbol{Z})$-11 に対して本連続反応を試みた ところ，相当する成績体 $\mathbf{1 2}$ が高收率で得られた。 この際，これまで確認できなかった $(E)$ - オレフィ ン部を持つ成績体 $(\boldsymbol{E})$-12 も同時に生成することが 明らかとなった。なお，ここでは転位の進行し易い シクロブタン環の $\alpha$ 位に 2 つ置換基を有する基質 を用いて立体選択性について検討を行つたが，一置 換体を用いても $\pi$-アリルパラジウム中間体を経る 転位反応は進行するものと考えられる。 ${ }^{11-13,16,17)} ま$
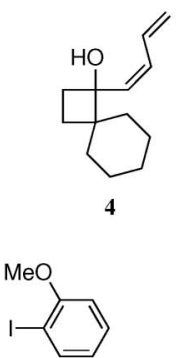

5b: $80 \%$

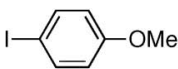

5f: $69 \%$
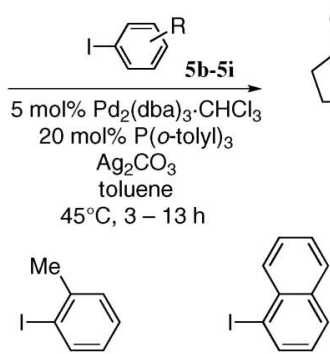

5c: $78 \%$

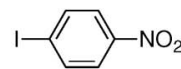

5g: $86 \%$ 5d: $56 \%$

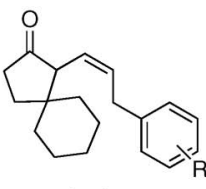

6b-6i

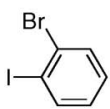

5e: $73 \%$

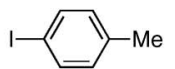

5h: $71 \%$

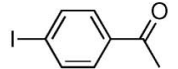

5i: $57 \%$
Fig. 3. Using Various Aryl Iodides 
たジエン末端に置換基を有するものは調製が困難で あったため検討を行っていない.

Table 1. Reaction Using Various 1-(1,3-dienyl) cyclobutanols with Iodobenzene ${ }^{a}$

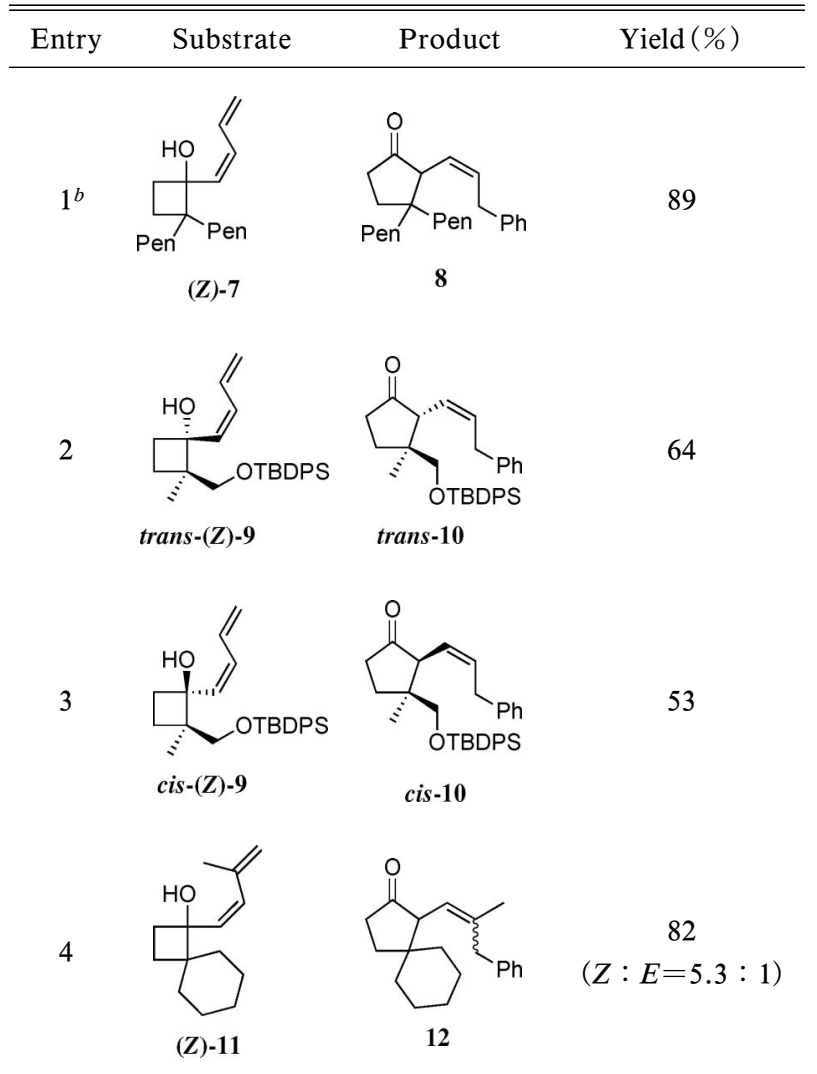

${ }^{a}$ All reactions were carried out in the presence of 1.5 equiv of iodobenzene, $5 \mathrm{~mol} \% \mathrm{Pd}_{2}(\mathrm{dba})_{3} \cdot \mathrm{CHCl}_{3}, 20 \mathrm{~mol} \% \mathrm{P}(o \text {-tolyl })_{3}$ and 2 equiv of $\mathrm{Ag}_{2} \mathrm{CO}_{3}$ in toluene at $45^{\circ} \mathrm{C}$ for $3-6 \mathrm{~h} .{ }^{b} \mathrm{Pen}=$ pentyl.
本反応の推定反応機構を Fig. 4 に示した. ジエ ニルシクロブタノール 15 は 0 価のパラジウムとヨ ウ化アリール 13 より生じるアリールパラジウム種 14 と挿入反応を起こし， $\sigma$-パラジウム錯体 16 を与 えると考えられる。ついで $\pi$-アリルパラジウム中 間体 17 を形成し, ${ }^{23)}$ これを引き金とした転位反応 が進行しシクロペンタノン $\mathbf{1 8}$ と導かれたものと 推測される.

次に，本反応において観察された立体選択性発現 機構について以下に示す（Fig. 5)。基質である $Z$ 型のジエニルシクロブタノールは，反応系中にてジ エン側鎖が置換基 $\mathrm{R}^{1}$ 及び置換基 $\mathrm{R}^{2}$ との立体反発 を避けて，（Z）-14のようなコンフォメーションを とっていると推測される。このジエン部位に対しア リールパラジウム種は基質中のヒドロキシル基との キレーションによって誌面手前側より接近し (19)， ${ }^{24 ）}$ 位置及び立体選択的な挿入をすることで $\sigma$ パラジウム錯体 20 を形成後, syn 型の $\pi$-アリルパ ラジウム中間体 syn-21 を生成すると考えられる.

ここでパラジウムは，シクロブタン環 $\alpha$ 位置換基 $\mathrm{R}^{1}, \mathrm{R}^{2}$ との立体反発を避けようと, $\pi-\sigma-\pi$ の異性 化を経て転位する炭素とは反対側に配向し，anti 型 の $\pi$-アリル錯体 anti-21 を生じ，より電子豊富な多 置換炭素が転位が進行することで $Z$ 型のオレフィ ンを持つ成績体 $(Z)-22$ を立体特異的に与えたもの と推測した.

一方， $E$ 型のジエニルシクロブタノールからは反

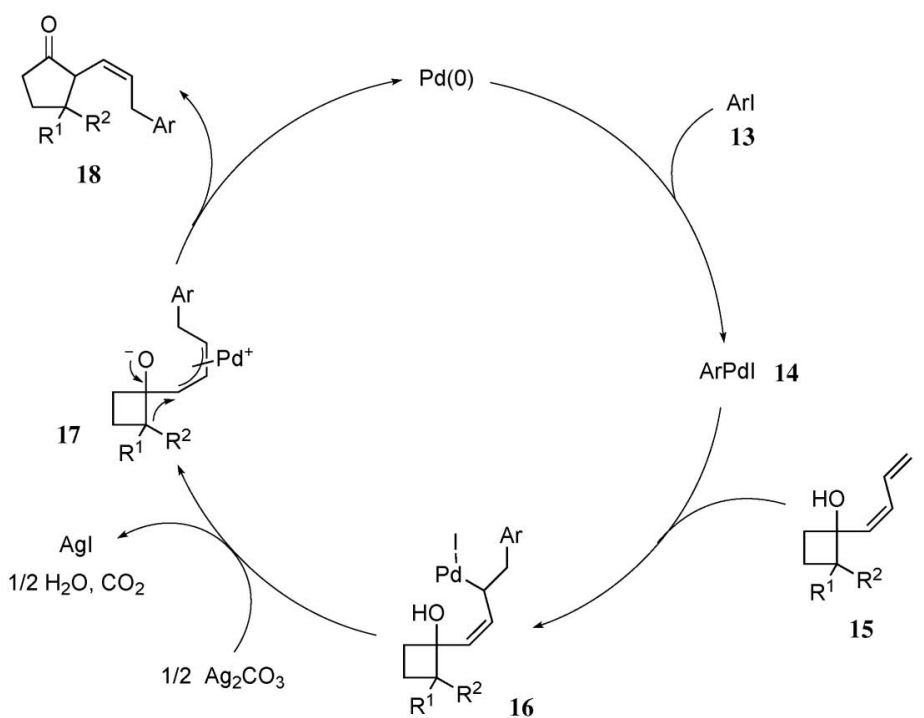

Fig. 4. Plausible Reaction Mechanism for Domino Ring Expansion Reaction 

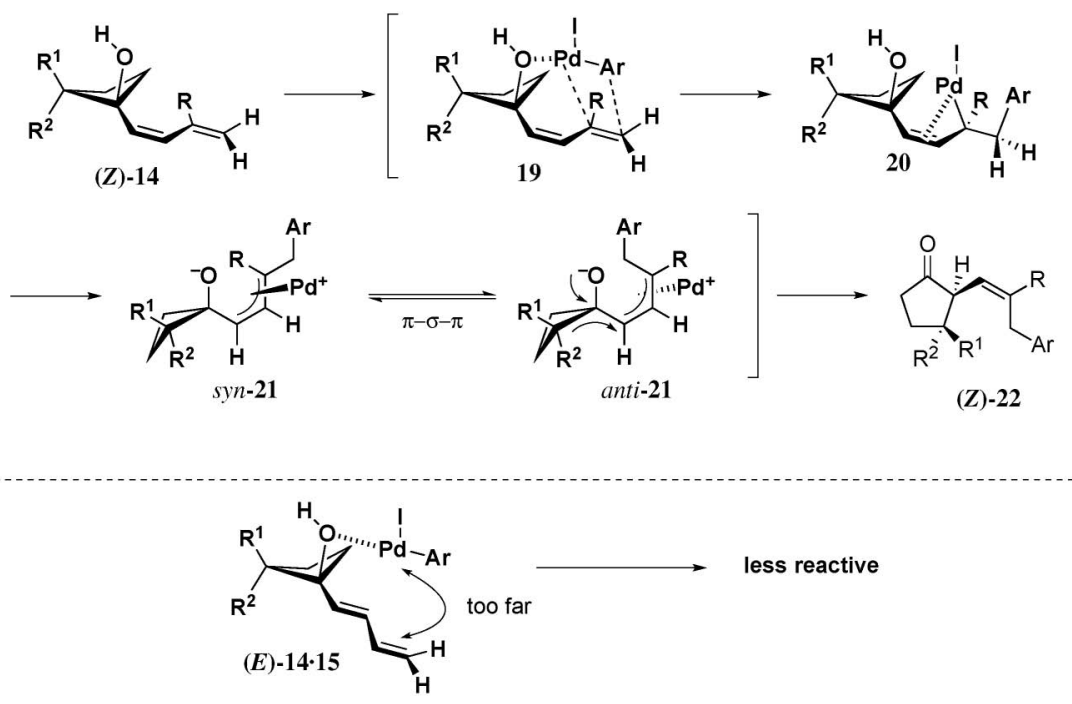

Fig. 5. Rationale for Stereoselectivity of Ring Expansion Reaction
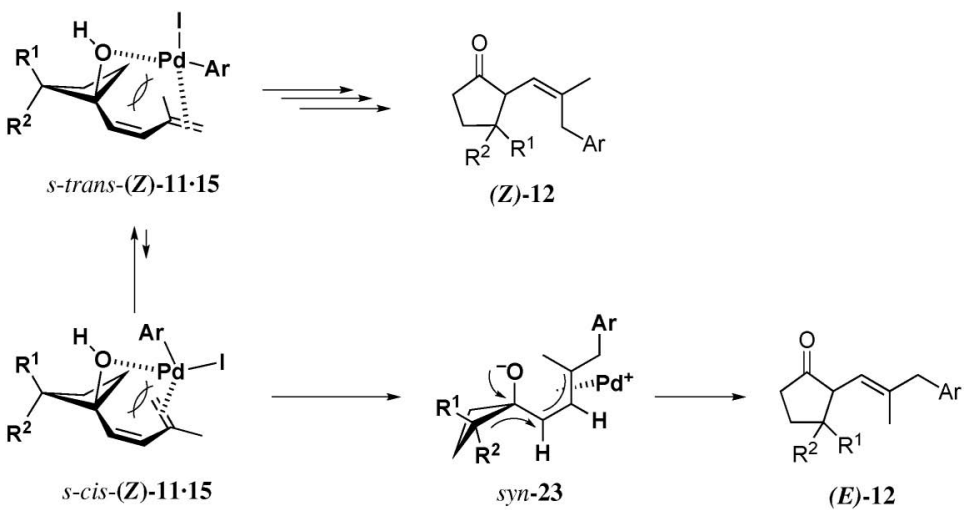

Fig. 6. Mechanism for Production of $(E)-12$

応が進行しなかったが, その理由は以下のように推 測した。 $(\boldsymbol{E})-14$ とアリールパラジウム種より生成 すると予想される中間体 $(\boldsymbol{E}) \mathbf{- 1 4} \cdot \mathbf{1 5}$ において, 水 酸基とジエン末端とが遠く位置し, 挿入反応が進行 し難かつたためであると考えた.

ジエン上 3 位にメチル基を有する基質 $(Z)$-11 用いた際には $E$ 型の成績体も共生したが，その理 由は次のように説明できる (Fig. 6)。先と同様に ジエン部位は置換基 $\mathrm{R}^{1}$ 及び $\mathrm{R}^{2}$ との立体反発を避 けたコンフォメーションで位置していると考えられ るが，シクロブタン環とジエン上のメチル基との立 体的要因により s-trans- $(Z)-11 \cdot 15$ のみではなく $s$ cis- $(Z)-11 \cdot 15$ との 2 種のコンフォマーの混合物と して存在すると予想される。これらからそれぞれ転 位が進行することで $(Z)-12$ とともに $(E)-12$ が生 じることになるが，これらのうちシクロブタン環と
アリールパラジウムの立体反発が小さくアリールパ ラジウムとの挿入が容易な s-trans- $(Z)-11 \cdot 15$ から 優先的に反応が進行し, $(Z)-12$ を選択的に与えて いると推測した。

3. ルテニウム触媒を用いたアセチレニルシクロ ブタノールの連続的環拡大反応 ${ }^{25)}$

続いて, ルテニウム触媒を用いた多重結合の活性 化を経る連続的環拡大反応の開発を行った。近年,

Trost らによってルテニウム錯体による三重結合の 活性化と続く求核剤との反応を経てビニルルテニウ ムが発生し，これにオレフィンが挿入することが報

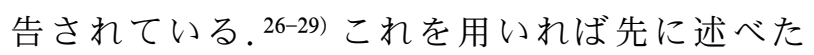
Heck 型のプロセスのように共生成物として酸が発 生せず，直接的に三重結合の活性化-転位反応一オレ フィン挿入反応が可能であると予測し, アセチレニ ルシクロブタノールの連続反応への適用を試みた. 
Table 2. Initial Attempt on $\mathrm{C}-\mathrm{C}$ Bond Formation-Ring Expansion Reaction

\begin{tabular}{|c|c|c|c|c|}
\hline & $\stackrel{\text { HO }}{a}$ & 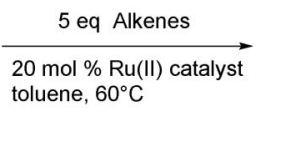 & 5 & 26 \\
\hline Entry & Alkene & $\mathrm{Ru}$ (II) catalyst & Time (h) & Product \\
\hline 1 & & {$\left[\mathrm{RuCl}_{2}(\mathrm{CO})_{3}\right]_{2}$} & 24 & complex mixture \\
\hline 2 & & {$\left[(p \text {-cymene }) \mathrm{RuCl}_{2}\right]_{2}$} & 24 & complex mixture \\
\hline 3 & & $\mathrm{Cp}^{*} \mathrm{Ru}(\operatorname{cod}) \mathrm{Cl}$ & 24 & complex mixture \\
\hline 4 & & {$\left[\mathrm{CpRu}(\mathrm{MeCN})_{3}\right] \mathrm{PF}_{6}$} & 24 & no reaction \\
\hline 5 & & $\mathrm{CpRu}\left(\mathrm{PPh}_{3}\right)_{2} \mathrm{Cl}$ & 24 & $\mathbf{2 5}(13 \%)$ \\
\hline 6 & $\widehat{\gamma} \widehat{0}$ & $\mathrm{CpRu}\left(\mathrm{PPh}_{3}\right)_{2} \mathrm{Cl}$ & 24 & no reaction \\
\hline 7 & & $\mathrm{CpRu}\left(\mathrm{PPh}_{3}\right)_{2} \mathrm{Cl}$ & 10 & $\begin{array}{c}26(60 \%) \\
(Z):(E)=5.7: 1^{a}\end{array}$ \\
\hline
\end{tabular}

${ }^{a}$ The ratio was determined by isolation of the each products.

スチレンの存在下アセチレニルシクロブタノール 24 に対し種々のルテニウム触媒を作用させたが, 目 的とした連続反応は進行せず，唯一 $\mathrm{CpRu}\left(\mathrm{PPh}_{3}\right)_{2}$ $\mathrm{Cl}^{30)}$ を用いた際に，転位のみ進行した成績体 25 が 低収率ながら得られた（Table 2)。さらにオレフィ ンについて検討を行ったところ，エチルビニルエー テルでは反応が進行しなかったが，MVKを用いた 際に目的とした転位と挿入とが連続的に進行し，60 \%の収率でアルキリデンシクロペンタノン 26 を得 ることに成功した。

さらに反応温度, additive の検討による反応最適 化を行った（Table 3)。その結果，反応温度 $60^{\circ} \mathrm{C}$ にて最も良好な結果を与えることがわかり，Lewis 酸として $\mathrm{CeCl}_{3}$ の添加が効果的であることを見い出 した。なお，この際，Brønsted 酸及び Lewis 塩 基・Brønsted 塩基の添加は収率の大幅な減少をも たらしたことから，この連続的な転位反応には，挿 入する MVK の活性化が重要であることが示唆され た. ${ }^{31)}$

ルテニウム触媒上の配位子の効果について調べた ところ，興味深い知見が得られた（Table 4)。電子 供与性，電子求引性いずれの置換基を持つ単座ホス フィンを配位子とするルテニウム触媒 ${ }^{32,33)}$ を用いて も相当する $(\boldsymbol{Z})-26$ を選択的に与えるのに対し，二 座配位子を有する錯体 ${ }^{34)}$ を用いると，反応時間の延 長と収率の大幅な低下が確認された。また，反応溶 液中で容易に配位子が解離し得る $\left[\mathrm{CpRu}\left(\mathrm{CH}_{3}\right.\right.$ $\left.\mathrm{CN})_{3}\right] \mathrm{PF}_{6}{ }^{35-37)}$ を用いると, $\mathrm{CpRu}\left(\mathrm{PPh}_{3}\right)_{2} \mathrm{Cl}$ を用い
Table 3. Optimization of Reaction Conditions for Domino Ring Expansion Reaction

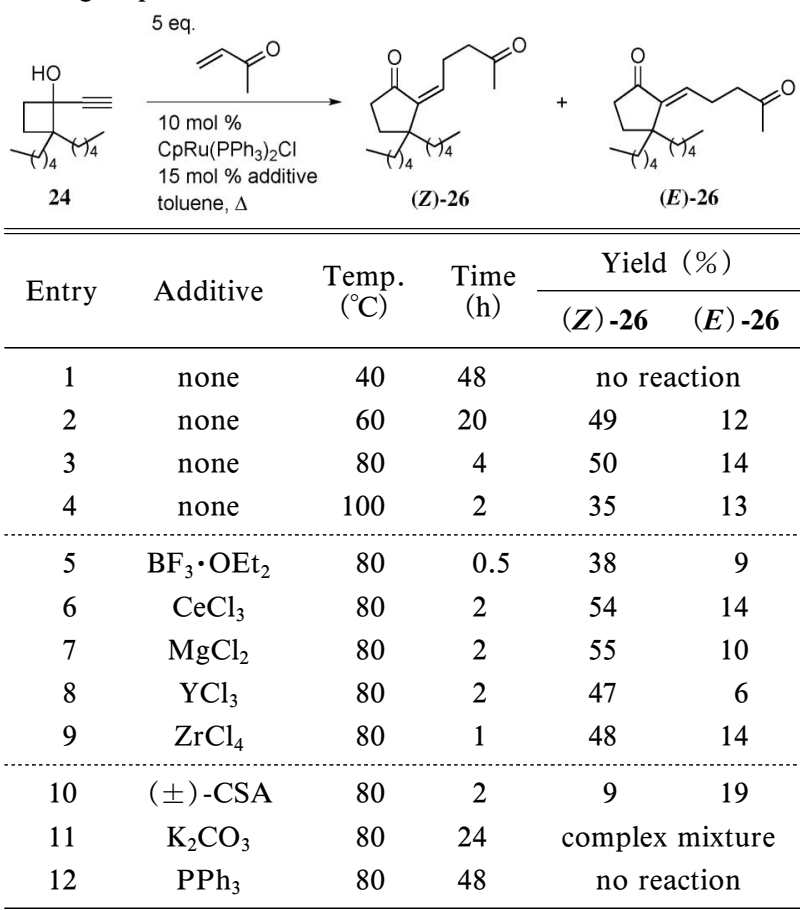

た際と同様の収率で成績体を与えるものの， $(\boldsymbol{E})$ -26が優先して得られる結果が得られた。 さらに, この $\left[\mathrm{CpRu}\left(\mathrm{CH}_{3} \mathrm{CN}\right)_{3}\right] \mathrm{PF}_{6}$ を用いても，ホスフィ ン配位子の共存下では $(\boldsymbol{Z})-\mathbf{2 6}$ の生成が優先するこ とが分かった.

$(E)-26$ 及び $(Z)-26$ の生成機構について, $(E)$ 26 を熱力学的条件での成績体であると予測し, 更 なる検討を行った（Table 5).38）すなわち一度単離 
Table 4. Phosphine Ligand Effect

\begin{tabular}{|c|c|c|c|c|c|}
\hline \multirow{2}{*}{ Entry } & \multirow{2}{*}{\multicolumn{2}{|c|}{$\mathrm{Ru}(\mathrm{II})$ catalyst }} & \multirow{2}{*}{$\underset{(\mathrm{h})}{\mathrm{Time}}$} & \multicolumn{2}{|c|}{ Yield (\%) } \\
\hline & & & & $(Z)-26$ & $(E)-26$ \\
\hline 1 & \multicolumn{2}{|c|}{$\mathrm{CpRu}\left(\mathrm{PPh}_{3}\right)_{2} \mathrm{Cl}$} & 2 & 54 & 14 \\
\hline 2 & \multicolumn{2}{|c|}{$\mathrm{CpRu}\left[\mathrm{P}(p \text {-tolyl })_{3}\right]_{2} \mathrm{Cl}$} & 2 & 50 & 11 \\
\hline 3 & \multicolumn{2}{|c|}{$\mathrm{CpRu}\left[\mathrm{P}\left(p-\mathrm{F}-\mathrm{C}_{6} \mathrm{H}_{4}\right)_{3}\right]_{2} \mathrm{Cl}$} & 1 & 49 & 10 \\
\hline 4 & \multicolumn{2}{|c|}{$\mathrm{CpRu}(\mathrm{dppm}) \mathrm{Cl}$} & 28 & $9(17)^{a}$ & $6(11)^{a}$ \\
\hline 5 & \multicolumn{2}{|c|}{$\left[\mathrm{CpRu}(\mathrm{MeCN})_{3}\right] \mathrm{PF}_{6}$} & 4 & 17 & 46 \\
\hline $6^{b}$ & \multicolumn{2}{|c|}{$\left[\mathrm{CpRu}(\mathrm{MeCN})_{3}\right] \mathrm{PF}_{6}+\mathrm{PPh}_{3}$} & 10 & 38 & 12 \\
\hline $7^{b}$ & \multicolumn{2}{|c|}{$\left[\mathrm{CpRu}(\mathrm{MeCN})_{3}\right] \mathrm{PF}_{6}+\mathrm{P}(p \text {-tolyl })_{3}$} & 4.5 & 37 & 10 \\
\hline $8^{b}$ & \multicolumn{2}{|c|}{$\left[\mathrm{CpRu}(\mathrm{MeCN})_{3}\right] \mathrm{PF}_{6}+\mathrm{P}\left(p-\mathrm{F}-\mathrm{C}_{6} \mathrm{H}_{4}\right)_{3}$} & 5 & 41 & 12 \\
\hline $8^{b}$ & \multicolumn{2}{|c|}{$\left[\mathrm{CpRu}(\mathrm{MeCN})_{3}\right] \mathrm{PF}_{6}+\mathrm{P}\left(p-\mathrm{MeO}-\mathrm{C}_{6} \mathrm{H}_{4}\right)_{3}$} & 4 & 46 & 1 \\
\hline
\end{tabular}

${ }^{a}$ The yields in parentheses are based on recovered starting materials. ${ }^{b} 20 \mathrm{~mol} \%$ phosphines were added as ligands.

Table 5. Conversion of $(Z)-\mathbf{2 6}$ to $(E)-\mathbf{2 6}$

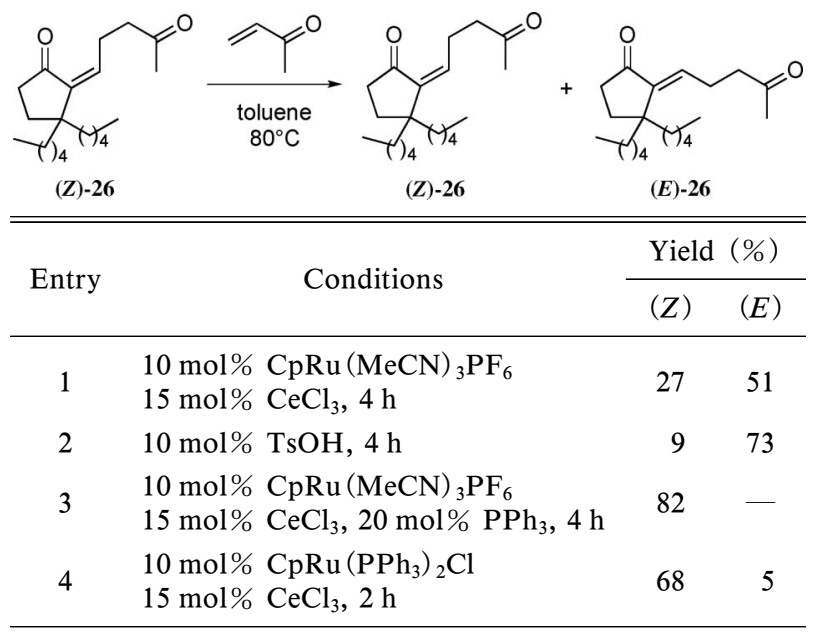

精製した（Z）-26から（E）-26への異性化実験を行 つたところ，先の環拡大反応にて $(\boldsymbol{E})-26$ を選択的 に与えた条件では，顕著な（E）-26への異性化がみ られた。この異性化は TsOH 触媒存在下において も観察された一方で， $(Z)-26$ を選択的に与えた連 続反応の条件では異性化がほとんど進行しなかった ことから，ホスフィン配位子の弱い塩基性により $\mathrm{CeCl}_{3}$ の酸性が抑制されていると考えられる。すな わち， $(\boldsymbol{E})-\mathbf{2 6}$ の生成は，連続的転位一挿入反応条件 下での酸性条件にて異性化により引き起こされてい るものと推測した。

以上をまとめると，本反応の機構は次のように考 えられる（Fig. 7)。まず反応系中にて少なくとも 1

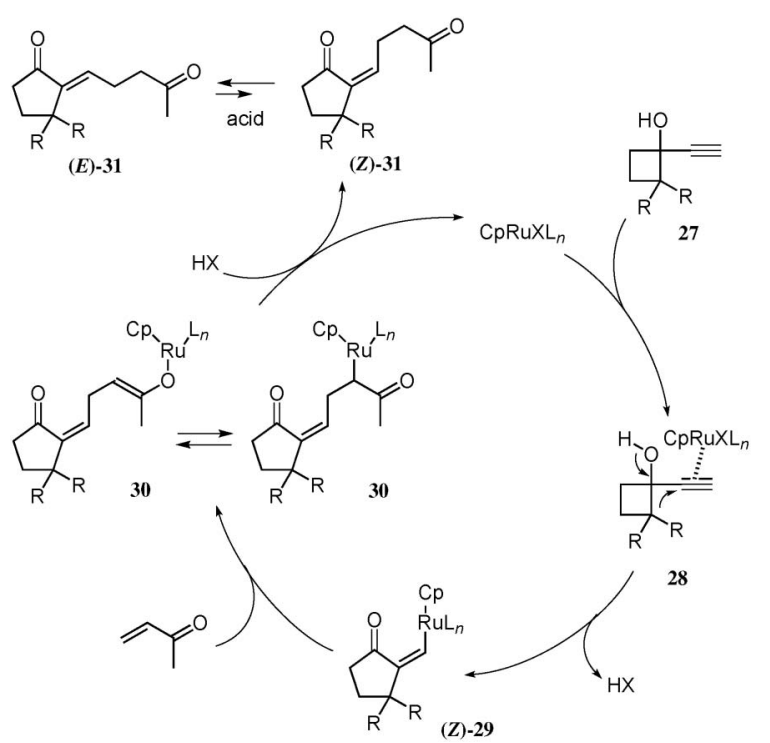

Fig. 7. Plausible Reaction Mechanism

つ配位座の空いたルテニウム錯体が 27 のアセチレ ン部位に配位し，活性化することで，四員環上の炭 素がアセチレン上の炭素へと転位し (28)，ビニル ルテニウム種 29 を生成する。 さらにこれに対して MVK の挿入反応が起こり，ルテニウムエノレート 30 若しくは 31 を経てプロトン化を受けることで (Z) -31 を与えるものと考えられる。ささらにこの (Z) -31 は, ホスフィン配位子非存在下では $(E)-31$ への異性化が促進されるものと推測した。

本反応を種々の基質に対して適用した（Table 6)。その結果，配位性の置換基を持つ基質で例外が 
Table 6. Ruthenium-catalyzed Domino Reaction of Acetylenyl Cyclobutanols

\begin{tabular}{|c|c|c|c|c|c|c|c|}
\hline \multirow{2}{*}{ Entry } & \multirow{2}{*}{ Substrate } & \multirow{2}{*}{ Product } & & \multirow{2}{*}{$\mathrm{Ru}$ catalyst } & \multicolumn{2}{|c|}{ Yield (\%) } & \multirow{2}{*}{$\begin{array}{l}\text { Total } \\
(\%)\end{array}$} \\
\hline & & & & & $(Z)$ & $(E)$ & \\
\hline 1 & & & & $\mathrm{CpRu}\left(\mathrm{PPh}_{3}\right)_{2} \mathrm{Cl}$ & 42 & 9 & 51 \\
\hline 2 & & & ${ }_{(E)-33}$ & $\mathrm{CpRu}(\mathrm{MeCN})_{3} \mathrm{PF}_{6}$ & 23 & 33 & 56 \\
\hline 3 & & & & $\mathrm{CpRu}\left(\mathrm{PPh}_{3}\right)_{2} \mathrm{Cl}$ & 33 & 12 & 45 \\
\hline 4 & 34 & ()-35 & $(E)-35$ & $\mathrm{CpRu}(\mathrm{MeCN})_{3} \mathrm{PF}_{6}$ & 12 & 50 & 62 \\
\hline 5 & & & & $\mathrm{CpRu}\left(\mathrm{PPh}_{3}\right)_{2} \mathrm{Cl}$ & 38 & 26 & 64 \\
\hline 6 & 36 & $(Z)-37$ & $(E)-37$ & $\mathrm{CpRu}(\mathrm{MeCN})_{3} \mathrm{PF}_{6}$ & 17 & 54 & 71 \\
\hline 7 & Ho & & & $\mathrm{CpRu}\left(\mathrm{PPh}_{3}\right)_{2} \mathrm{Cl}$ & 43 & 15 & 58 \\
\hline 8 & 38 & $(Z)-39$ & (E) -39 & $\mathrm{CpRu}(\mathrm{MeCN})_{3} \mathrm{PF}_{6}$ & 3 & 49 & 52 \\
\hline 9 & $\stackrel{\mathrm{HO}}{=}=$ & & & $\mathrm{CpRu}\left(\mathrm{PPh}_{3}\right)_{2} \mathrm{Cl}$ & 3 & 46 & 49 \\
\hline 10 & $\mathrm{MeO}^{\mathrm{OMe}}$ & MeO & $\mathrm{Me} \quad(\boldsymbol{E})-41$ & $\mathrm{CpRu}(\mathrm{MeCN})_{3} \mathrm{PF}_{6}$ & 7 & 57 & 64 \\
\hline
\end{tabular}

みられるものの (Entries 9 and 10), 先と同様に, 用いる反応系によって $(Z)$-体， $(E)$-体の生成比を 制御できることが分かった.

\section{DIBALHを用いたオキシムの還元的転位反 応 ${ }^{39,40)}$}

芳香環に窒素原子が直接結合した環状アミンは, 医薬の母核として頻繁にみられ，このような複素環 基本骨格の合成法の開発は有機合成化学及び医薬品 化学の視点から重要な課題である。そのため, ベン ゾアゼピンやチエノアゼピンなどの段階的な合成法 が開発されてきているが，最近，直接的な合成法と して，DIBALH を用いたオキシムの還元的転位反 応が見い出された。本らは鎖状対称オキシムの転 位反応を報告し, ${ }^{41-43)}$ 長らは, フランやチオフェン など芳香環に縮環した環状オキシムに対して適用す ると，オキシムの幾何異性に関係なく芳香環からの 転位が進行した第二級環状アミンが単一の成績体と して得られることを見い出し，医薬品候補化合物の 合成に適用している（Fig. 8).44-47）しかしながら， 本法の一般性や反応機構に関しての知見がそしく, 詳細について明らかにされていなかつたため，これ らを明らかにすべく検討を開始した。

一般性について検証するべく種々の二環性環状ケ トンからオキシムを調製し，DIBALH を用いた還 元的転位反応を試みた（Fig. 9)。その結果，ベン ゼン環と縮環した二環性ケトンやへテロ環と縮環し

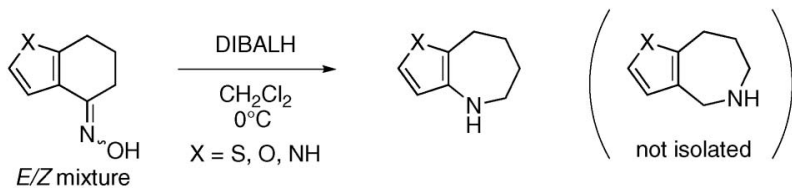

Fig. 8. DIBALH-mediated Reductive Ring Expansion Reaction of Oximes
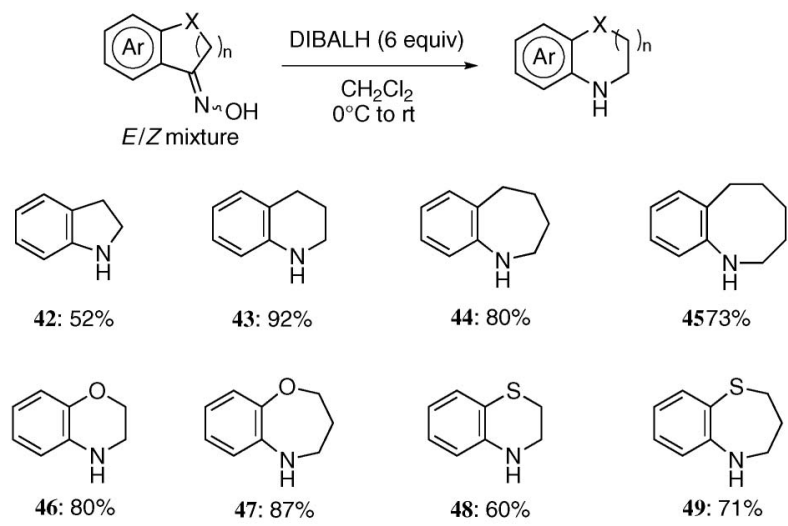<smiles>c1ccc2c(c1)CCCN2</smiles>

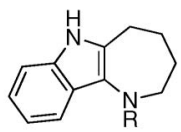

50: $63 \%$

$(\mathrm{R}=p$-nitrobenzoyl)

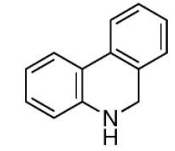

51: $69 \%$

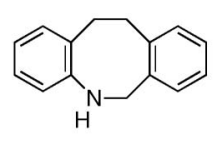

52: $60 \%$
Fig. 9. DIBALH-mediated Reductive Ring Expansion Reaction of Various Oximes

た二環性ケトンから調製したオキシムでは問題なく 目的とした還元的転位反応成績体 42-49 を得ること 
ができた。さらに三環性ケトンに対してもオキシム 化し，還元的転位反応を適用すると，第二級アミン 50-52 を与え, 複素環のみならずベンゼン環と縮環 したオキシムでも適用可能であることが分かった. なお，成績体 $\mathbf{5 0}$ に関しては，生成した第二級アミ ンが不安定であったため, ベンゾイル化の後単離し た.

続いて反応機構について知見を得るべく，実験的 及び計算化学的アプローチを試みた。まず初めに, $(E)$-体，（Z)-体いずれのオキシムからも単一の成 績体を与えることや，DIBALH が還元剤及び Lewis 酸として機能することをふまえ，以下のよう な反応機構を想定した（Fig. 10）。すなわち，1 等 量目の DIBALH によって 53 のオキシム酸素上の 脱プロトンが進行し 54 となり，続いて 2 等量目の DIBALH がオキシム二重結合を還元し 55 を生じる と考えた。この段階で原料であるオキシム 53 の幾 何異性は生成物には反映されないこととなり，ここ でなんらかの形で転位が進行しイミニウムカチオン 中間体 56 となった後, さらに 3 等量目の DIBALH がこれを還元し，57に至ると推測した.

これを実証すべく，実際に 53 のオキシム二重結 合を $\mathrm{NaBH}_{3} \mathrm{CN}$ により還元し, ${ }^{48,49)}$ ヒドロキシルア ミン 58 を単離した後，これに対して DIBALH を 作用させることとした（Fig. 11）。中間体 $\mathbf{5 5}$ の生 成を仮定すると，必要な DIBALH はオキシムを基 質とした場合と同量であると考えられたため，これ までと同様の条件にて反応を行ったところ，才キシ ムを原料とした際と同一の環状第二級アミン 44 が 得られることが分かった。

さらに Gaussian 03 プログラムを用いた密度汎関 数法（DFT 法）に基づく解析を行った。 ${ }^{50)}$ 先に示
した 54 から 56 への反応経路の B $3 \mathrm{LYP} / 6-31 \mathrm{G}(\mathrm{d})$ による解析によると，この過程は 1 つの中間体 TS1 を経る段階的な機構で進行していることが分かった (Figs. 12 and 13). エネルギーダイヤグラムから, 律速段階は B から TS1 を経由して Cへと至る過程 であり，この段階で転位の選択性が決定されること が明らかとなった。 ヒドロキシルアミン誘導体の最 安定コンフォメーションはヒドロキシルアミノ基が 擬エクアトリアル位を占める $\mathbf{A}$ であるが，転位反 応は，ヒドロキシルアミノ基が擬アキシアル位を占 め, 芳香環上の $\pi$ 電子が $\sigma_{\mathrm{N}-\mathrm{O}}^{*}$ 軌道に平行に存在 し，芳香環からの電子寄与が効果的に起こり得る $\mathbf{B}$

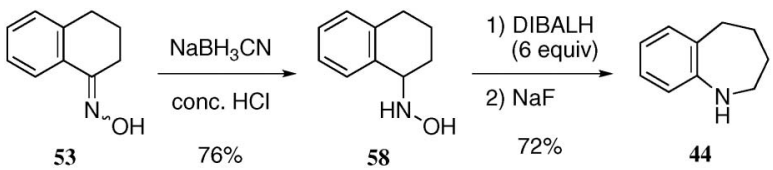

Fig. 11. Rearrangement from Hydroxylamine to Azepine

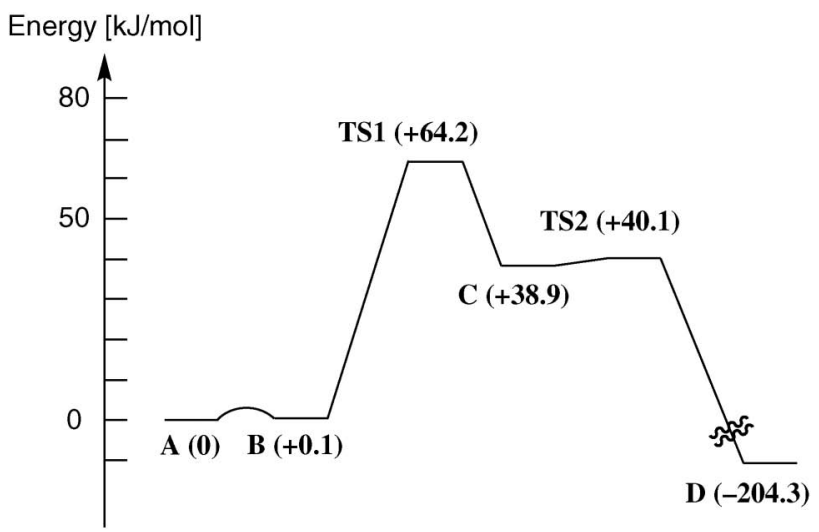

Fig. 12. Potential Energy Diagram of Ring Expansion Relative energies $(\mathrm{kJ} / \mathrm{mol})$ are shown in parentheses (B3LYP/6-31G (d)) .

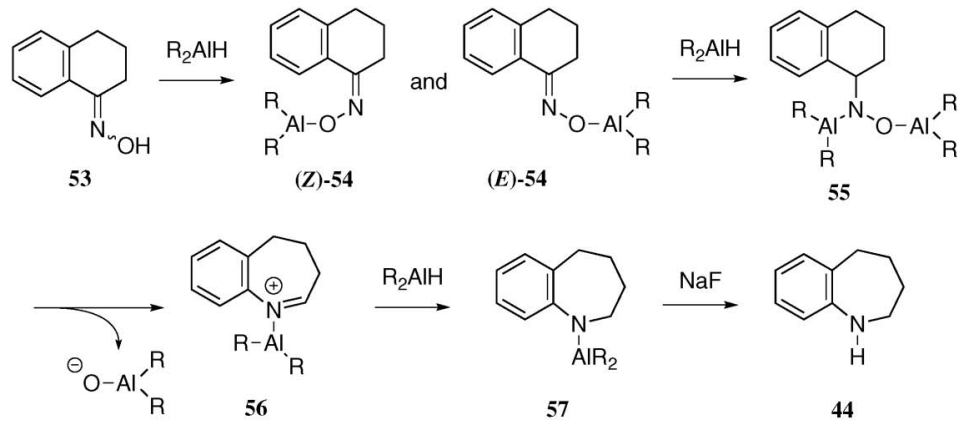

Fig. 10. Postulation of Reaction Mechanism 

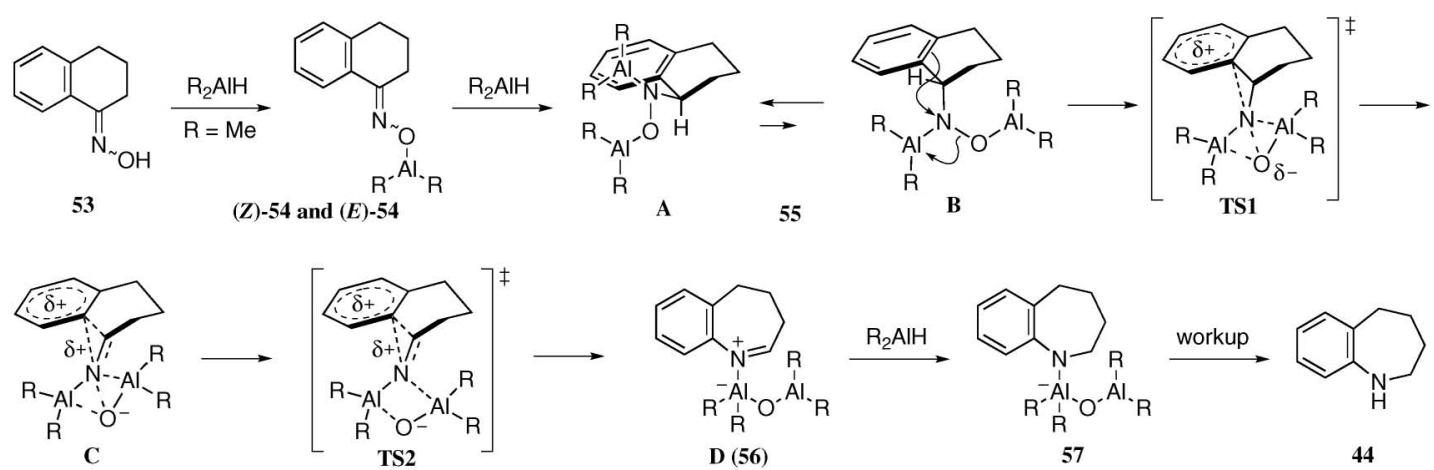

Fig. 13. Stepwise Mechanism Proposed by the Aid of B3LYP Method

から進行することが分かった．Bから $64.2 \mathrm{~kJ} / \mathrm{mol}$ のエネルギー障壁を有する 1 つ目の遷移状態 TS1 を経る際に N-O 結合の開裂とともに C1-N 結合が 形成され，フェノニウムカチオン様中間体 $\mathbf{C}$ とな るが， $\mathrm{C}$ から $1.2 \mathrm{~kJ} / \mathrm{mol}$ 高い 2 つ目の遷移状態を 容易に越えるため, 直ちに C1-C2 結合の開裂によ つて芳香族性を回復してイミニウム $\mathbf{D}$ へ至って いることが判明した.

芳香環の $\pi$ 電子が重要な役割を果たしているこ とは，次の実験からも強く示唆される (Table 7). すなわち，基質の立体的な要因を排除し，電子密度 の要因のみを反映させられるように，それぞれのべ ンゼン環のパラ位に置換基を有する非対称なベンゾ フェノンオキシム誘導体 59-61 を合成し, DIBALH を用いた還元的転位反応に適用した。その結果，転 位する芳香環はそれぞれの電子密度を明確に認識 し，より電子密度の高い芳香環のみが転位した 6264 を単一の成績体として与えることが明らかとな つた。対称性の高いベンゾフェノン誘導体から，2 つの芳香環のわずかな電子密度の差を活用した非対 称化が可能であることが示唆された興味深い結果で ある。

さらに鎖状ケトキシムへの適用と選択的転位の一 般性を調べたところ，転位する置換基の傾向は，芳 香環 $\geqq$ 第三級アルキル基 $>$ 第二級アルキル基 $>$ 第一 級アルキル基の順となり，Baeyer-Villiger 転位反応 と類似の挙動を示すことが分かった.

\section{5. おわりに}

以上のように，転位反応を基盤とした連続反応の 開発を試み，新たな展開を見い出すことができた。 パラジウム触媒を用いたジエニルシクロブタノール の連続的環拡大反応の開発に成功し，立体選択的に
Table 7. Reductive Rearrangement of Diaryl Ketone Oximes

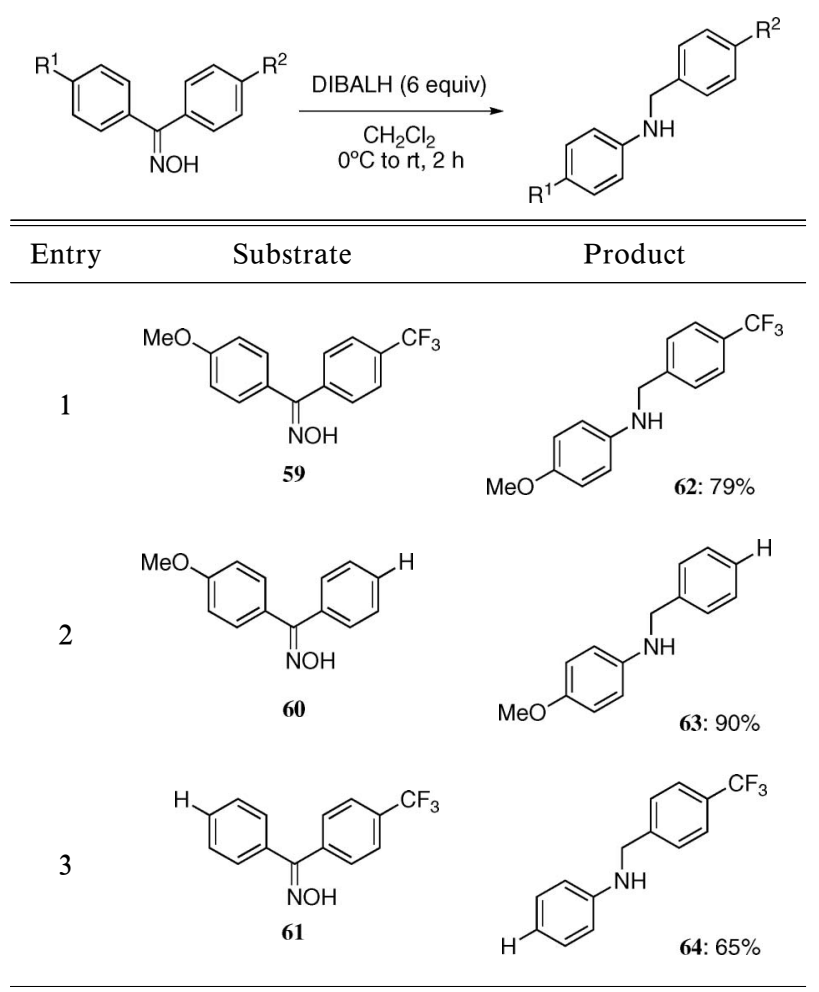

シクロペンタノン誘導体が得られることを明らかと し，その生成機構について重要な知見を得ることが できた。ささらに，新たな反応様式を経る連続的環拡 大反応の開発を試み, 多重結合の直接的な活性化に よる転位反応続く挿入反応を一挙に行うルテニウム 触媒によるアセチレニルシクロブタノールの連続的 環拡大反応を見い出した。 また，これまでに基質一 般性が確認されていなかったオキシムの還元的転位 反応について検討を行い，適用範囲を明らかとする とともに，未解明であった本反応の反応機構につい て重要な知見を得ることができた。いずれの場合 
も，立体選択的な転位反応が進行することから，今 後, 基質の設計により多様な成績体の精密な合成が 期待できる.

謝辞本稿で紹介した研究はすべて東北大学大 学院薬学研究科で行われたものであり, 多くのご指 導とご助言を賜りました井原正隆教授（東北大学名 誉教授・現星薬科大学特任教授)，徳山英利教授 (東北大学大学院薬学研究科), 長 秀連教授 (東北 大学大学院理学研究科・薬学研究科), 吉田昌裕准 教授（現徳島大学大学院薬学研究部）にこの場を借 りて深謝申し上げます。また，反応経路解析におい ては森 聖治准教授（茨城大学理学部）に多大なる ご支援を頂きました。ここに深謝致します。ここに 紹介しました研究成果は, 共同研究者の日々の努力 の結果得られたものであり，ここに感謝の意を表し ます，本研究の一部は，文部科学省科学研究費補助 金の援助により行われたものであり，併せて御礼申 し上げます。

\section{REFERENCES AND NOTES}

1) Tietze L. F., Beifuss U., Angew. Chem. Int. $E d ., 32,131-163$ (1993).

2) Tietze L. F., Chem. Rev., 96, 115-136 (1996).

3) Nicolaou K. C., Edmonds D. J., Bulger P. G., Angew. Chem. Int. Ed., 45, 7134-7186 (2006).

4) Tietze L. F., Brasche G., Gericke K. M., "Domino Reactions in Organic Synthesis," Wiley-VCH, Weinheim, 2006.

5) Padwa A., Bur S. K., Tetrahedron, 63, 53415378 (2007).

6) Enders D., Grondal C., Hüttl R. M., Angew. Chem. Int. Ed., 46, 1570-1581 (2007).

7) Nemoto H., Shiraki M., Fukumoto K., Synlett, 599-600 (1994).

8) Nemoto H., Miyata J., Yoshida M., Raku N., Fukumoto K., J. Org. Chem., 62, 7850-7857 (1997).

9) Nemoto H., Yoshida M., Fukumoto K., Ihara M., Tetrahedron Lett., 40, 907-910 (1999).

10) Yoshida M., Ismail M. A.-H., Nemoto H., Ihara M., J. Chem. Soc., Perkin Trans. 1, 2629-2635 (2000).

11) Nemoto H., Yoshida M., Fukumoto K., J. Org. Chem., 62, 6450-6451 (1997).
12) Yoshida M., Sugimoto K., Ihara M., Tetrahedron Lett., 41, 5089-5092 (2000).

13) Yoshida M., Sugimoto K., Ihara M., Tetrahedron, 58, 7839-7846 (2002).

14) Yoshida M., Sugimoto K., Ihara M., Tetrahedron Lett., 42, 3877-3880 (2001).

15) Yoshida M., Sugimoto K., Ihara M., $A R$ KIVOC, viii, 35-44 (2003).

16) Yoshida M., Nemoto H., Ihara M., Tetrahedron Lett., 40, 8583-8586 (1999).

17) Yoshida M., Komatsuzaki Y., Ihara M., Org. Biomol. Chem., 2, 3099-3107 (2004).

18) Yoshida M., Sugimoto K., Ihara M., Org. Lett., 6, 1979-1982 (2004).

19) Patel B. A., Dickerson J. E., Heck R. F., J. Org. Chem., 43, 5018-5020 (1978).

20) Patel B. A., Kao L. C., Cortese N. A., Minkiewicz J. V., Heck R. F., J. Org. Chem., 44, 918-921 (1979).

21) Stakem F. G., Heck R. F., J. Org. Chem., 45, 3584-3593 (1980).

22) Fischetti W., Mak K. T., Rheingold A. L., Heck R. F., J. Org. Chem., 48, 948-955 (1983).

23) The intermediate that palladium cation forms a bond to the alkoxide anion is also expected.

24) The conformation of $(Z)-\mathbf{1 4} \cdot \mathbf{1 5}$ was predicted from the result of MOPAC 97/PM3 calculation of $(Z)-\mathbf{1 4}$.

25) Sugimoto K., Yoshida M., Ihara M., Synlett, 1923-1927 (2006).

26) Trost B. M., Pinkerton A. B., J. Am. Chem. Soc., 121, 1988-1989 (1999).

27) Trost B. M., Pinkerton A. B., Angew. Chem. Int. Ed., 39, 360-362 (2000).

28) Trost B. M., Pinkerton A. B., Tetrahedron Lett., 41, 9627-9631 (2000).

29) Trost B. M., Pinkerton A. B., J. Am. Chem. Soc., 124, 7376-7389 (2002).

30) Bruce M. I., Windsor N. J., Aust. J. Chem., 30, 1601-1604 (1977).

31) Trost B. M., Pinkerton A. B., J. Am. Chem. Soc., 121, 4068-4069 (1999).

32) Walker L. F., Bourghida A., Connolly S., Wills M., J. Chem. Soc., Perkin Trans. 1, 965 -981 (2002).

33) Hartwig J. F., Bhandari S., Rablen P. R., $J$. Am. Chem. Soc., 116, 1839-1844 (1994).

34) Ashby G. S., Bruce M. I., Tomkins I. B., Wal- 
lis R. C., Aust. J. Chem., 32, 1003-1016 (1979).

35) Gill T. P., Mann K. R., Organometallics, 1, 485-488 (1982).

36) Trost B. M., Older C. M., Organometallics, 21, 2544-2546 (2002).

37) Kündig E. P., Monnier F. R., Adv. Synth. Catal., 346, 901-904 (2004).

38) MOPAC 2000/AM1 calculation indicated that $(E)$-26 is thermodynamically more stable than (Z) -26 by $0.79 \mathrm{kcal} / \mathrm{mol}$.

39) Cho H., Iwama Y., Sugimoto K., Kwon E., Tokuyama H., Heterocycles, 78, 1183-1190 (2009)

40) Cho H., Iwama Y., Sugimoto K., Mori S., Tokuyama H., J. Org. Chem., 75, 627-636 (2010)

41) Hattori K., Matsumura Y., Miyazaki T., Maruoka K., Yamamoto H., J. Am. Chem. Soc., 103, 7368-7370 (1981).

42) Sasatani S., Miyazaki T., Maruoka K., Yamamoto H., Tetrahedron Lett., 24, 4711-4712 (1983)

43) Fujiwara J., Sano H., Maruoka K., Yamamoto H., Tetrahedron Lett., 25, 2367-2370 (1984)

44) Cho H., Matsuki S., Heterocycles, 43, 127131 (1996).

45) Cho H., Murakami K., Nakanishi H., Isoshima H., Hayakawa K., Uchida I., Heterocycles, 48, 919-927 (1998).

46) Cho H., Murakami K., Fujisawa A., Niwa M., Nakanishi H., Uchida I., Heterocycles, 48, 1555-1566 (1998).

47) Cho H., Murakami K., Nakanishi H., Fujisa- wa A., Isoshima H., Niwa M., Hayakawa K., Hase Y., Uchida I., Watanabe H., Wakitani K., Aisaka K., J. Med. Chem., 47, 101-109 (2004).

48) Borch R. F., Bernstein M. D., Durst H. D., J. Am. Chem. Soc., 93, 2897-2904 (1971).

49) Gribble G. W., Leiby R. W., Sheeha M. N., Synthesis, 856-859 (1977).

50) Frisch M. J., Trucks G. W., Schlegel H. B., Scuseria G. E., Robb M. A., Cheeseman J. R., Montgomery J. A. Jr., Vreven T., Kudin K. N., Burant J. C., Millam J. M., Iyengar S. S., Tomasi J., Barone V., Mennucci B., Cossi M., Scalmani G., Rega N., Petersson G. A., Nakatsuji H., Hada M., Ehara M., Toyota K., Fukuda R., Hasegawa J., Ishida M., Nakajima T., Honda Y., Kitao O., Nakai H., Klene M., Li X., Knox J. E., Hratchian H. P., Cross J. B., Bakken V., Adamo C., Jaramillo J., Gomperts R., Stratmann R. E., Yazyev O., Austin A. J., Cammi R., Pomelli C., Ochterski J. W., Ayala P. Y., Morokuma K., Voth G. A., Salvador P., Dannenberg J. J., Zakrzewski V. G., Dapprich S., Daniels A. D., Strain M. C., Farkas O., Malick D. K., Rabuck A. D., Raghavachari K., Foresman J. B., Ortiz J. V., Cui Q., Baboul A. G., Clifford S., Cioslowski J., Stefanov B. B., Liu G., Liashenko A., Piskorz P., Komaromi I., Matrin R. L., Fox D. J., Keith T., Al-Laham M. A., Peng C. Y., Nanayakkara A., Challacombe M., Gill P. M. W., Johnson B., Chen W., Wong M. W., Gonzalez C., Pople J. A., Gaussian 03, revision D.02; Gaussian Inc., Wallingford, CT (2004). 